\title{
Microbial Purification in Well-Water Using UV-Vis LEDs and Monitoring Using Laser-Induced Fluorescence
}

\author{
Samuel Sonko Sackey ${ }^{1}$, Baah Sefa-Ntiri ${ }^{1}$, Patrick Mensah-Amoah ${ }^{1}$, Jonathan Ntow ${ }^{2}$, Michael Kwame Vowotor ${ }^{3}$, \\ Andrew Huzortey ${ }^{1} \&$ Angela Akyea $^{1}$ \\ ${ }^{1}$ Laser and Fibre Optics Centre, Department of Physics, University of Cape Coast, Ghana \\ ${ }^{2}$ Department of Laboratory Technology, University of Cape Coast, Ghana \\ ${ }^{3}$ Department of Physics, University of Cape Coast, Ghana \\ Correspondence: Samuel Sonko Sackey, Laser and Fibre Optics Centre, Department of Physics, University of Cape \\ Coast, Ghana. E-mail: samuel.sackey@ucc.edu.gh
}

Received: October 3, 2017

Accepted: October 20, 2017 Online Published: November 10, 2017

doi:10.5539/apr.v9n6p36

URL: https://doi.org/10.5539/apr.v9n6p36

\begin{abstract}
Well-water contaminated by microbial bacteria has been purified using LEDs radiating in the ultra-violet and visible spectral regions. The contaminated water sample was exposed to the LEDs in specially constructed chambers and the purification process carried on for 3 days. The efficiency of the process was determined using a $445 \mathrm{~nm}$ diode laser to induce fluorescence (LIF) and the monitoring of coliform bacteria count (Total coliform, Fecal coliform and Escherichia coli) as well as Total Heterotrophic Bacteria (THB). The LIF peak fluorescence intensities at $526 \mathrm{~nm}$ (Raman water peak) and dissolved organic matter fluorescence intensity at $550 \mathrm{~nm}$ were determined. Using the fluorescence intensity of purified drinking water as reference, a fluorescence intensity ratio was calculated. A decrease in this ratio with time, at the two wavelengths indicated a proof of purification. Using the values of the slopes, the red and green LEDs proved most efficient while the UV was the least. From the counts of coliform bacteria and THB, the light sources registered zero after the first day of purification, but counts were recorded thereafter for some of the bacterial for some light sources. This may be attributable to bio-films formation on internal surfaces of the purification chamber due to excessive temperatures. A reduction in fluorescence intensity observed in the sample stored in dark environment could be attributed to the stationary and logarithmicdecline phases of the growth curve of bacterial population. This purification technique is inexpensive and can easily be adapted for domestic water purification for reducing waterborne bacteria.
\end{abstract}

Keywords: coliform bacteria, Escherichia coli, laser induced fluorescence, microbial purification, total heterotrophic bacteria, ultra-violet and visible spectral regions

\section{Introduction}

Water is associated with life, and indeed needed by all living things for survival. Its deficiency in active cells results in dehydration and has caused many deaths and adverse health situations. Its quality is a powerful determinant of good health, and has therefore gained a critical attention. This is because it is often contaminated by micro-organisms such as pathogenic enteric bacteria, viruses, intestinal parasites and other unwanted chemical substances leading to a reduction in its quality. Water of poor quality is a health hazard, with the most predominant waterborne disease, diarrhea, having an estimated annual incidence of 4.6 billion episodes and causing 2.2 million deaths every year. It results in malnutrition, weakness, and an increase in vulnerability to diseases which can be life threatening. In Africa, about $42 \%$ of healthcare providers do not have access to clean water, while globally, 663 million people (about 10\%) do not have access to safe drinking water (WHO/UNICEF JMP Report, 2015). If authorities do not take measures to resolve such fundamental human need for safe and portable water, about 135 million people will die from water-related diseases by 2020 (Gleick, 2002).

The wholesomeness of water means absence of suspended solids, inorganic solids and pathogens which are disease-causing organisms. Ideally, water must contain only its molecules without any contaminants. The Safe Drinking Water Act defined contaminant as any physical, chemical, biological, or radioactive substance or matter present in water (Contaminant Candidate List, 2016). The exponential growths in the population of most 
developing countries have put pressure on the quality of water sources due to the rise in waste production without the requisite increase in waste management techniques and facilities to handle the situation.

Ghana is endowed with water resources from rainfall, surface water (rivers, lakes, ponds and streams) and groundwater sources (springs and wells), but the latter has proved to be cost-effective and a long-lasting source of water supply. This has led to the drilling of over 10,000 boreholes and over 45,000 hand-dug wells in the country. $50 \%$ of the entire population use water from groundwater sources while the rural communities, which form about $70 \%$ of the total population, rely mostly on groundwater source for all chores (ISODEC, 2011).

One way of assessing the quality of groundwater is by monitoring dissolved organic matter (DOM) as its concentration can reflect the possibility of contamination (Leenheer et al., 1974; Barcelona, 1984). Humic and fulvic acids of DOM affect the solubility of organic pollutants in groundwater and can contribute to the long-range transport of harmful chemicals (Chiou et al., 1986) which in groundwater can lead to production of carcinogenic disinfection byproducts (DBPs) during drinking water treatment (Singer, 1994; Chomycia et al., 2008). According to Tebbute (1992), traces of pathogenic organisms are found in groundwater as a result of poor well-construction techniques which are associated with bedrock aquifers in which large openings afford direct connection between the surface and groundwater

Poorly constructed, cracked or unsealed wells can provide an avenue for coliform bacteria to enter groundwater. Coliform bacteria are a group of microorganisms found in soils, surface water and on plants, but can be washed into groundwater by rain. Such bacteria are used as pointers in water tests as their presence indicates that pathogens could also be in the water. Analysis is conducted for three different groups of coliform bacteria, with each having a well-defined level of risk to human health. Total coliform bacteria are generally harmless and may have the environment as its source. Fecal coliform bacteria (sub-group of total coliform bacteria) appear in great quantities in the feces of people and animals. Escherichia coli (E. coli) are found in great quantities in the intestines of warmblooded animals including humans. Some strains can cause illness, and their detection indicates fecal contamination of a well and poses a high risk for illness from disease-causing organisms (Coliform Bacteria, 2016; Water Fact Sheet, 2009). The regular monitoring and testing for coliform bacteria in groundwater is necessary to ensure the supply of safe water to consumers.

Another quality assessment considered an accessory indicator in the measurement of coliform in water is the heterotrophic plate count (HPC). This is an aerobic-anaerobic bacteria test used for monitoring general bacteriological water quality, but cannot be used in fecal contamination test (Hsu et al., 1995). Heterotrophic bacteria are not indicators of pathogenic conditions, but can cause infections in skin, lung and gastroenteritis (Bartram et al., 2003; Chopra \& Houston, 1999, Helmer et al., 1997). Heterotrophic bacteria are present in all water types (Foulquier et al., 2011; Griebler \& Lueders, 2009) and drinking water treatment does not remove or inactivate all heterotrophic organisms. Some are resistant because they may be in a spore or vegetative form with an impervious membrane, or may be protected from treatment as part of an aggregate (Geldreich, 1996). Their concentration in water varies from less than $1 \mathrm{CFU} / \mathrm{ml}$ (colony forming unit per milliliter) to over $10000 \mathrm{CFU} / \mathrm{ml}$ (Payment, 1999; Pepper et al., 2004; Stine et al., 2005) and depends on temperature and the amount of absorbable organic material. The maximum permissible level of heterotrophic bacteria in potable water is $500 \mathrm{CFU} / \mathrm{ml}$ (Amanidaz et al., 2015). In groundwater, under the direct influence of surface water, their concentrations can be highly variable. Such variations can be sudden or gradual over time and may indicate a change in water quality.

Water purification techniques which aim at removing all contaminants in order to make it safer for use have existed, while new and more efficient ones have recently been discovered and employed. Some basic purification methods in use include filtration (eliminates most of suspended particles), oxygenation (allows atmospheric oxygen to dissolve in the water killing microbes), solar disinfection, chlorination and reverse osmosis. Some of these techniques may be expensive and saddled with disadvantages. Chlorination water treatment, for instance, leaves behind disinfection by-products (DBPs) which may have adverse birth defects and outcomes and causes bladder cancer (Villanueva et al., 2006).

Purification using light sources involves exposing organism in contaminated water to radiations mainly within the ultra-violet (UV) and visible (Vis) parts of the electromagnetic spectrum. This results in inactivating both pathogenic and non-pathogenic bacteria (Hamamoto et al., 2007) as the rays strike and penetrates the outer cell membrane, going through the cell body and disrupting the DNA -preventing reproduction (Here, nothing is being added except the energy which does the killing). Such radiation has the potential of causing destruction to a lot of bacteria species; mold spores, algae, virus, and yeast based on the dose of energy delivered to the organism by the radiation and do not form any significant DBPs (Oppenheimer et al., 1997). With respect to the use of light sources, LEDs are preferred and have been receiving tremendous attention amongst researchers over the past few years. 
They use electricity more efficiently, do not require any warm up-period and it is possible to adjust their wavelengths to supply desirable radiations (Jo, 2013; Nelson et al., 2013; Crook, 2011; Vilhunen et al., 2011). UV LEDs in particular are used to inactivate chlorine-resistant pathogens within a relative short contact time without producing undesirable DBPs during water treatment (Ibrahim et al., 2013; Bowker et al., 2011; Crawford et al., 2005).

Simple and non-destructive spectroscopic methods using various light sources have been shown to be useful in the structural and functional studies of DOM (Chin et al., 1994). Lasers and LEDs have been used for disinfection in water (Adeboye, 2014; Gondal et. al., 2009; Copa \& Gitchel, 1981) while induced fluorescence using these same sources (LIF for lasers) have been used to estimate water pollution and probe the composition of DOM in watersheds (Sharikova, 2009).

The objective of this study is to assess the efficiency of purification in groundwater harvested from a heavily patronized hand-dug well located near the University of Cape Coast by determining its fluorescence spectra and measuring the count of coliform bacteria (Total coliform, Fecal coliform and Escherichia coli) and Total Heterotrophic Bacteria (THB) before and after treating with different LED sources within the UV-Vis spectral regions. The extent of purification using each source is also analyzed.

\section{Materials and Methods}

\subsection{Study Area}

The University of Cape Coast is located in the Central Region of Ghana $\left(05^{\circ} 06^{\prime} 00^{\prime \prime} \mathrm{N}, 01^{\circ} 15^{\prime} 00^{\prime \prime} \mathrm{W}\right)$ with no elevation above sea level. Within the immediate environs of the University is Amamoma, a settlement where a large number of the students of the university live. Availability of water is usually a problem in Cape Coast and its environs and therefore most inhabitants tend to rely on hand-dug wells for their daily chores. Figure 1 is a composite figure in which (a) is a map of Ghana highlighting the Central Region, (b) shows the study area Amamoma and (c) shows area details within Amamoma indicating the investigated well.
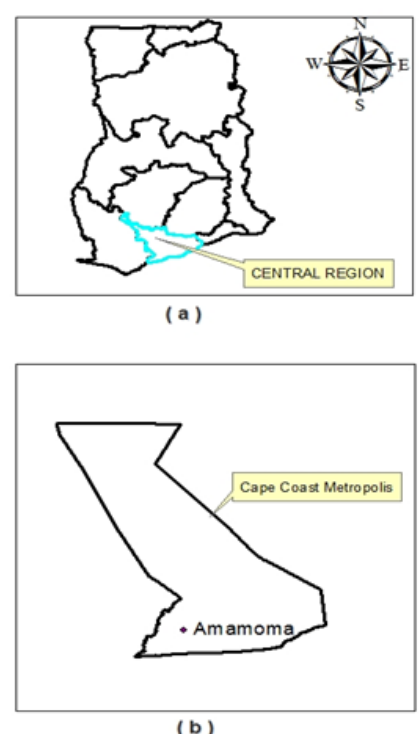

(b)

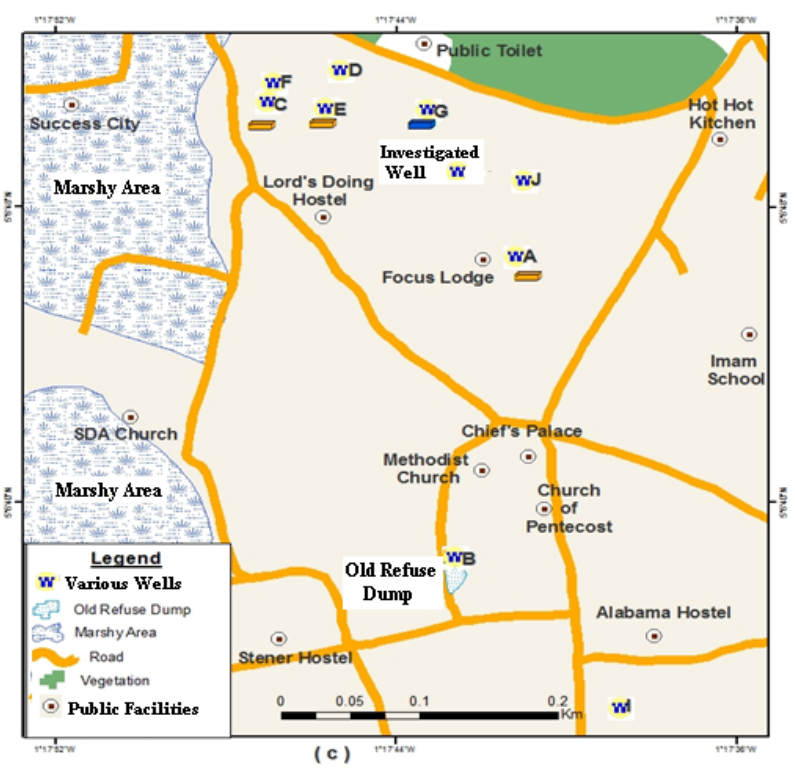

Figure 1. (a) Map of Ghana highlighting the Central Region, (b) Study area Amamoma, (c) Details within Amamoma showing the investigated

\subsection{Microbiological Experimental Procedure}

Using the Ghana Standards Authority guidelines (Ghana Standards Authority, 2009), the pour-plate technique was used to analyse the sample for coliform bacteria (Total coliform, Fecal coliform and Escherichia coli) and Total Heterotrophic Bacteria (THB) all in CFU per mL. The samples were collected into sterilized plastic containers before noon, kept under ice and transported to the laboratory for processing within a few hours of collection. Culture media (Plate Count Agar [Oxoid Ltd., Hampshire, England] and Eosin Methylene Blue Agar [Oxoid Ltd., Hampshire, England]) were prepared according to the manufacturer's instructions and sterilized at $121^{\circ} \mathrm{C}, 15 \mathrm{psi}$ for 15 minutes. Each sample was shaken vigorously and the area around the lid of the bottle wiped with clean tissue soaked with $70 \%$ ethanol (Aseptic technique). 
Duplicate dilutions of $0.1 \mathrm{~mL}$ and $1 \mathrm{~mL}$ of each sample were inoculated on plate count agar using the spread and pour plate technique respectively and incubated at $37^{\circ} \mathrm{C}$ for 48 hours. All colonies were counted, and an average of duplicate samples recorded as THB counts $/ \mathrm{mL}$ (CFU/milliliter) for the sample.

Similarly, 2 duplicate dilutions of $0.1 \mathrm{~mL}$ and $1 \mathrm{~mL}$ of each sample were plated on Eosin Methylene Blue agar and one incubated at $37^{\circ} \mathrm{C}$ for 48 hours to observe for TC and the other duplicate incubated at $44^{\circ} \mathrm{C}$ for 48 hours to observe for FC. All purple colonies were counted, and an average of duplicate samples recorded as TC and FC counts $/ \mathrm{mL}(\mathrm{CFU} / \mathrm{mL})$, respectively for the sample.

For Escherichia coli each of the presumptive colonies (metallic green sheen colonies on the FC) was sub-cultured in $10 \mathrm{~mL}$ of Peptone Water (Oxoid) for biochemical testing. Each colony was grown in peptone water and incubated at $44^{\circ} \mathrm{C}$ for 24 hours. A drop of Kovac's reagent was then added to the tube of peptone water. All the tubes showing a red ring color development after gentle agitation indicated the presence of indole and recorded as a confirmation of Escherichia coli. All colonies of that morphological type were then enumerated and recorded.

\subsection{Overview of Construction of Purification Chamber and Optical System Used}

\subsubsection{Purification Chamber}

A vacuum thermos flask ( 1 liter volume) was used as the purification chamber and was chosen because it could provide and ensure an efficient and easily-maintained system. A glass tube was driven through a rubber cork and LED arranged on strips wound round the tube. The terminals of the LED were passed through the rubber cork. A specially fabricated white glass tube made of quartz was then lowered to the base of the cork to serve as an outer shield to protect the LED. This is as shown in Figures $2 \mathrm{a}$ and $2 \mathrm{~b}$. The shielded LED on the glass tube was then lowered into a flask, which served as the purification chamber, as shown in Figure 2c. The material used to protect the LED needed to be transparent in the UV-Vis spectral regions. A white quartz glass, which is transparent in the visible region, was therefore used as a previous study had confirmed its transparency in the UV region (Sackey et. al., 2015).

\subsubsection{Design Involving LEDs}

Five different LEDs (green, red, ultra-violet, white and blue) along with five flasks respectively were used. The reflecting inner surface of the flask ensured an even distribution of light while at the same time confining the heat generated within the purification environment. The LEDs were powered by a $12 \mathrm{~V}$ DC supply. Figure $2 \mathrm{~b}$ shows the powered LEDs.

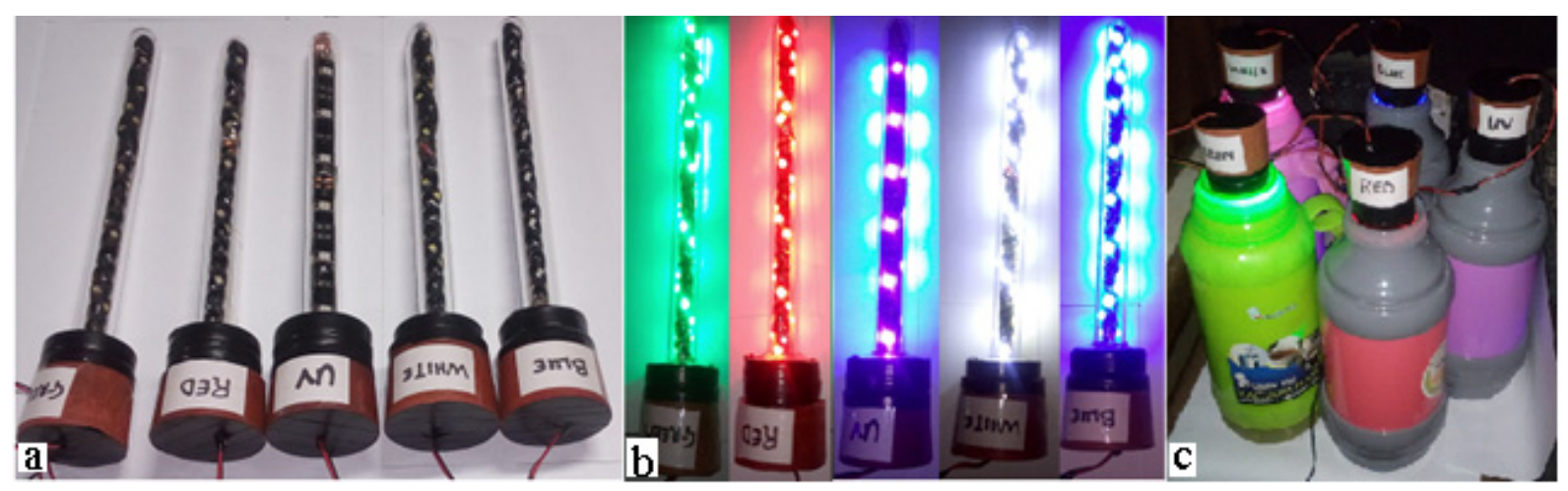

Figure 2: (a) Fabricated tube showing the LED's housed and protected within the quartz glass material. (b) The various LED's powered. (c) The individual purification chambers for the various LED's

\subsection{Laser Induced Fluorescence (LIF) Set-up}

A Laser induced fluorescence (LIF) set-up was used to monitor and analyze the DOM content of the water samples (the well-water and natural drinking water used as reference) before and after exposure, which was carried out for a period of three (3) days, with measurements being carried out after every 24 hours. The experimental set-up is as shown in Figure 3. It consists of a diode laser source emitting at $445 \mathrm{~nm}$, a detector mounted perpendicular to the laser and an optical fiber cable that couples light from the detector into the spectrometer. A computer was used for data collection and analysis. 


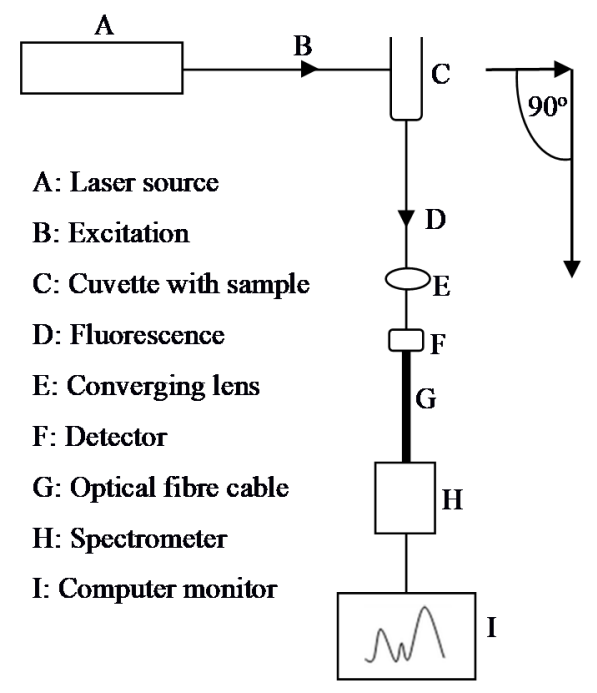

Figure 3. LIF setup for DOM measurements

\section{Results and Discussions}

The spectra of the LEDs used were first taken using a USB 4000 spectrometer to determine the wavelength at which they each exhibited their maximum intensities. The graphs for their normalized spectra are shown in Figure 4.

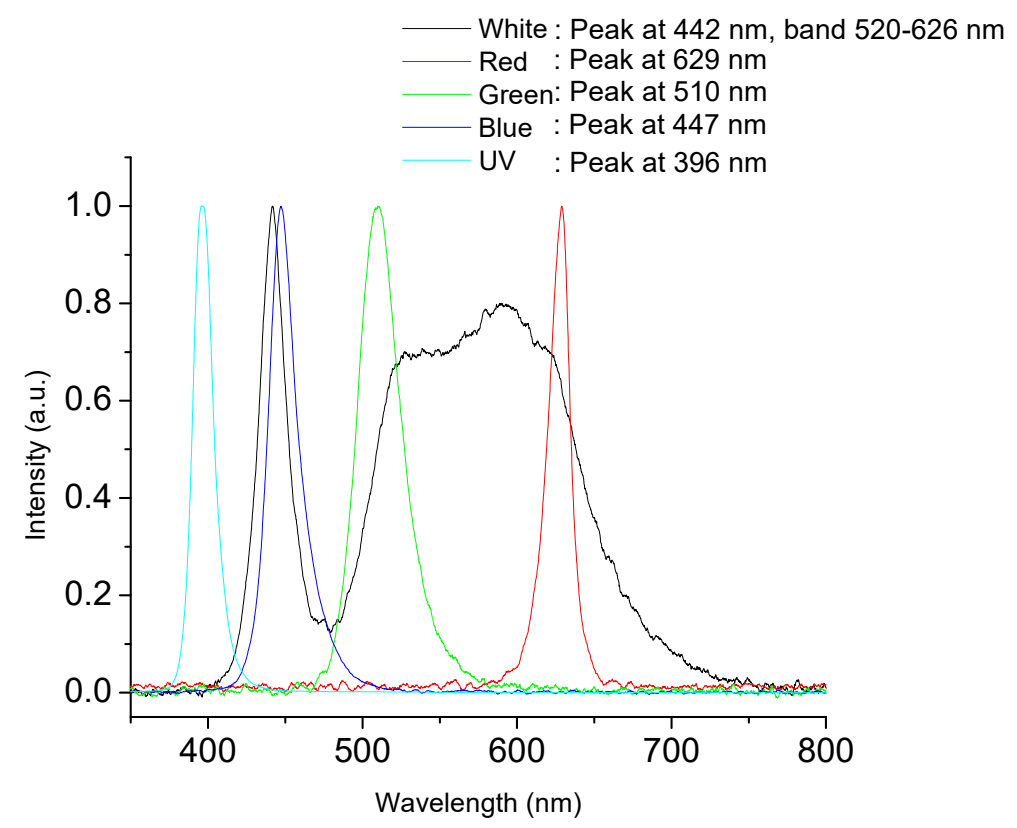

Figure 4. Normalized spectral emissions of the different LED sources used

\subsection{Temperature Analysis on Purification Chamber}

Two distinctive analyses involving temperature were carried out on each of the purification chambers. The first was a study conducted before the commencement of the purification process to determine the rate of heat loss from each flask. This was done by filling each flask with water at a temperature of $95^{\circ} \mathrm{C}$, and the temperature measured after every hour for 4 hours. The temperature variations, which are represented in the vertical column graph in Figure 5, indicate a similar rate of heat loss for all 5 purification chambers. The second analysis involved a determination of the temperature within the purification chamber each time data was to be collected. As expected, the LEDs warmed-up with time; therefore this measurement provided the temperature of the sample at each time of measurement. The findings of these measurements for each LED are represented in Figure 6. The initial temperature reading for all the samples was $27^{\circ} \mathrm{C}$. 


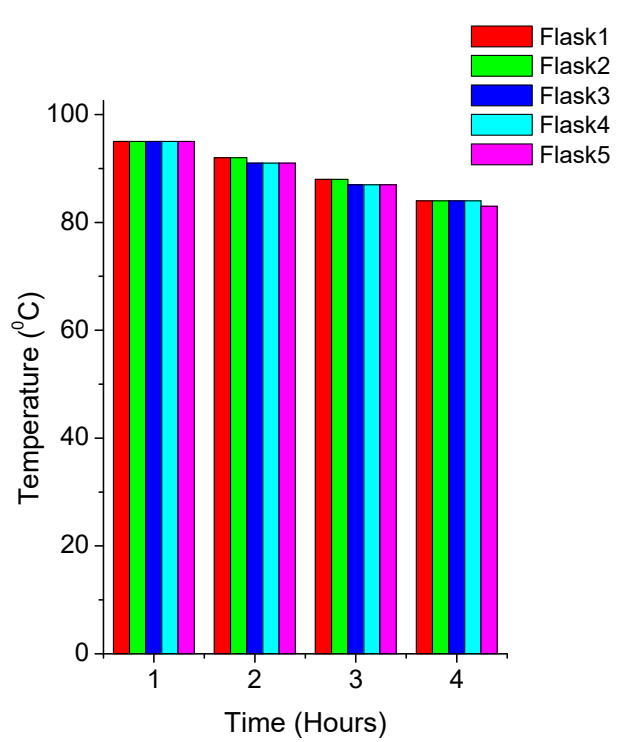

Figure 5. Temperature variations with time within each purification chamber indicating similar rate of heat loss for all 5 flasks from an initial temperature of $95^{\circ} \mathrm{C}$

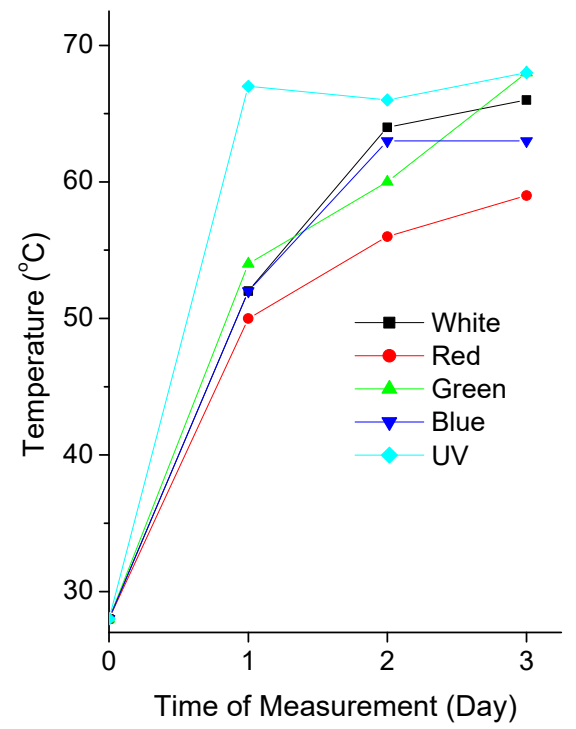

Figure 6. Variations in temperature within the purification chamber for the various LEDs each time data was collected

\subsection{LIF DOM Measurements}

The LIF from the samples were determined for each light source used and for the 3 days of purification. Figure 7 is a composite graph showing the LIF after each day of purification. For each plot, a comparison is made with the natural drinking mineral water (represented as 'purified') and the original non-purified water sample (represented by 'NT'). The plot labeled 'Dark' is for the control untreated sample kept in a completely dark environment throughout the study period.
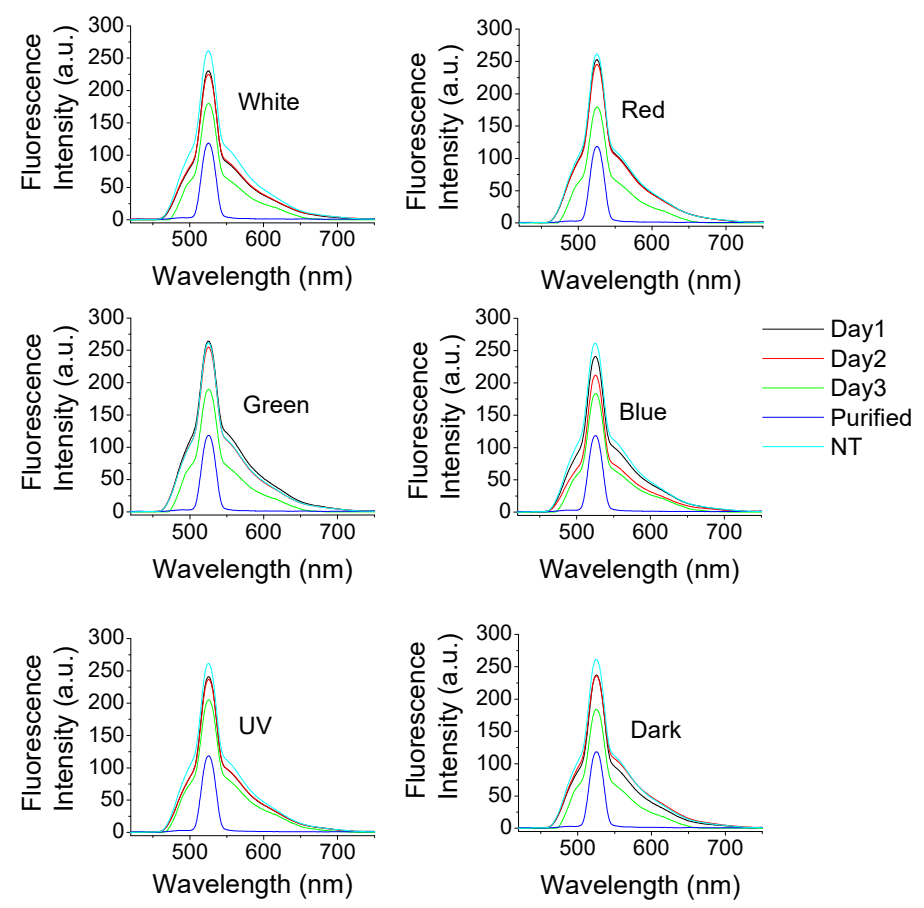

Figure 7. Composite graph showing the LIF of the samples after purification using the various LEDs and comparing with the natural drinking mineral water ('purified') and the original non-treated water sample kept in a completely dark environment ('NT') 
Comparing the plots with the plot for natural drinking mineral water (purified), it is noticed that both the peak fluorescence intensity at $526 \mathrm{~nm}$ (Raman water peak) and DOM fluorescence intensity at $550 \mathrm{~nm}$ reduced from Day 1 to Day 3 for all the LEDs used. This can be assigned to photo-degradation. Additionally, it will be noticed that the fluorescence intensity for the sample stored in the dark environment (control) also decreased with time, meaning that something else aside the photo-degradation was taking place. This observation has been explained under section 3.3: Analysis Based on Colony formation before and after purification. There was no shoulder observed on the graph for the natural drinking water (purified) at $550 \mathrm{~nm}$ and can be assigned to the fact that the natural drinking water has no DOM. DOM are only observed for contaminated water samples and was therefore only observed for the water samples collected from the well.

Using the fluorescence intensity of the purified drinking water as reference, a fluorescence intensity ratio (FIR) was calculated after each day of purification and for each light source at $526 \mathrm{~nm}$ and $550 \mathrm{~nm}$. This was calculated using the equation below.

$$
F I R=\frac{F I_{S}}{F I_{N D W}}
$$

where $F I_{S}$ is the fluorescence intensity of the sample at a given time (Day) of purification, for a given LED and emission wavelength (526 nm or $550 \mathrm{~nm}$ ), and $F I_{N D W}$ is the fluorescence intensity of the natural drinking mineral water which was used as the reference. Figure 8 is a composite graph for the variation of the FIR for the different LEDs with time. Figure $8 \mathrm{a}$ represents the ratios at $526 \mathrm{~nm}$ while Figure $8 \mathrm{~b}$ represents the ratios at $550 \mathrm{~nm}$.
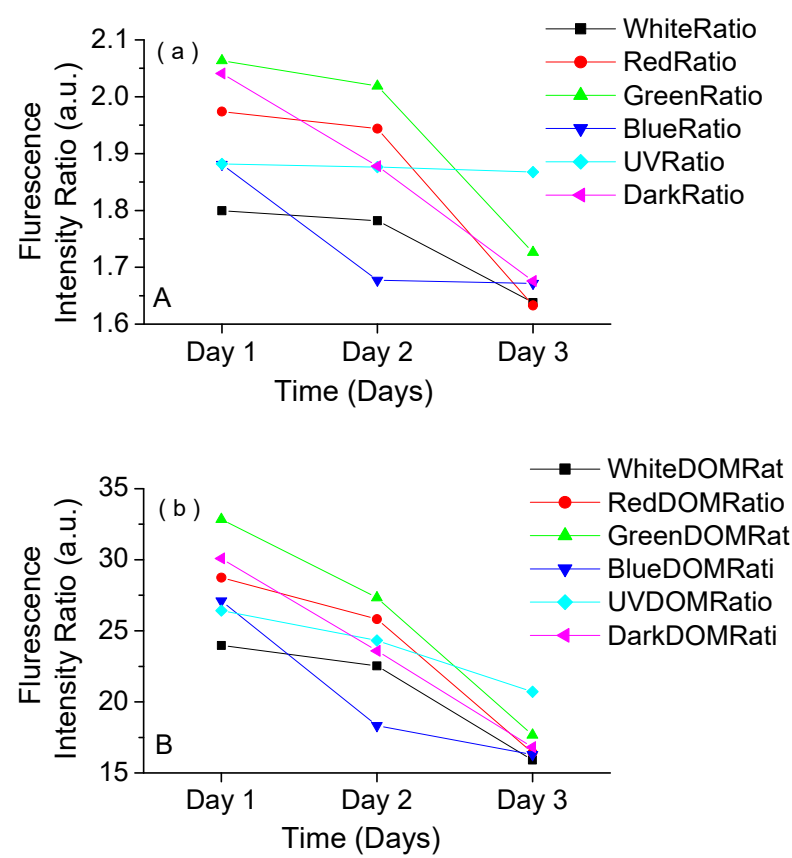

Figure 8. Changes in fluorescence intensity ratios for the different LEDs with time at (a) $526 \mathrm{~nm}$ and (b) $550 \mathrm{~nm}$

It is clear from Figure 8 that the DOM substances in the water sample appear to be more sensitive to the visible light sources than the UV light source and therefore photo-degradation was more pronounced with the visible light sources. Generally, the fluorescence intensity ratios (FIR) calculated for the various light sources at $526 \mathrm{~nm}$ and $550 \mathrm{~nm}$ decreased with time and indicates an improvement in the quality of the water and a confirmation of some purification. Using the data obtained from the FIR, a line of best fit was drawn, a linear equation established for each light source $(526 \mathrm{~nm}$ and $550 \mathrm{~nm}$ ) and the slope of each line determined and used as an indicator of the rate and efficiency of purification. Higher slope values indicated a faster and more efficient purification process. Table 1 gives the values of the slopes extracted from Figure 8 and the ranking for the LEDs at $526 \mathrm{~nm}$ and $550 \mathrm{~nm}$. 
Table 1. Slope values and ranking of the LEDs at $526 \mathrm{~nm}$ and $550 \mathrm{~nm}$ respectively

\begin{tabular}{ccc}
\hline & Fluorescence Intensity Ratios at 526 nm & Ranking using slope \\
\hline LEDs & Slope & 4 \\
White & -0.08067 & 1 \\
Red & -0.17032 & 2 \\
Green & -0.16854 & 3 \\
Blue & -0.10463 & 5 \\
UV & -0.00715 & \\
\hline & Fluorescence Intensity Ratios at 550 nm & 2 \\
LEDs & Slope & 1 \\
White & -4.02791 & 3 \\
Red & -6.16064 & Ranking using slope \\
Green & -7.58613 & 5 \\
Blue & -5.40900 & \\
UV & -2.85325 & \\
\hline
\end{tabular}

It can be deduced that at both $526 \mathrm{~nm}$ and $550 \mathrm{~nm}$, the red and green LEDs proved most efficient in the DOM purification process, while the UV was the least efficient. This observation made with respect to the UV conforms to a previous study that drinking water purification using UV LEDs is not an efficient technique (Adeboye, 2014).

\subsection{Analysis Based on Colony Formation before and after Purification}

There was a count of coliform bacteria (Total coliform, Fecal coliform and Escherichia coli) and Total Heterotrophic Bacteria (THB) before purification and a regular periodic count on a daily basis. These counts, as measured in Colony Forming Unit per milliliter CFU/ml, before purification (NT) and for the 3 days of purification using the various light sources, are presented in Table 2. The count for the sample stored in the dark is also presented.

Table 2. Microbial Population (CFU/ml) before and after purification with the various light sources and for the 3 days of treatment

\begin{tabular}{|c|c|c|c|c|c|c|c|}
\hline & \multicolumn{7}{|c|}{ Microbial Population (CFU/ml) after Day 1 purification using the LEDs } \\
\hline & NT & Dark & White & Red & Green & Blue & UV \\
\hline TC & $1.20 \times 10^{3}$ & $5.78 \times 10^{2}$ & NG & NG & NG & NG & NG \\
\hline $\mathrm{FC}$ & $1.60 \times 10^{3}$ & $8.80 \times 10^{1}$ & NG & NG & NG & NG & NG \\
\hline E.coli & $4.90 \times 10^{1}$ & $\mathrm{NG}$ & NG & NG & NG & NG & NG \\
\hline THB & $2.70 \times 10^{3}$ & $2.50 \times 10^{3}$ & NG & NG & NG & NG & NG \\
\hline \multicolumn{8}{|c|}{ Microbial Population (CFU/ml) after Day 2 purification using the LEDs } \\
\hline TC & $1.20 \times 10^{3}$ & $1.09 \times 10^{2}$ & NG & $1.10 \times 10^{1}$ & NG & NG & $9.80 \times 10^{1}$ \\
\hline $\mathrm{FC}$ & $1.60 \times 10^{3}$ & $8.90 \times 10^{1}$ & NG & NG & $9.00 \times 10^{0}$ & NG & $4.60 \times 10^{1}$ \\
\hline E.coli & $4.90 \times 10^{1}$ & $2.10 \times 10^{1}$ & NG & NG & $1.30 \times 10^{1}$ & NG & $9.00 \times 10^{0}$ \\
\hline THB & $2.70 \times 10^{3}$ & $6.80 \times 10^{1}$ & $4.00 \times 10^{0}$ & $5.00 \times 10^{0}$ & $7.90 \times 10^{1}$ & $2.00 \times 10^{0}$ & $1.00 \times 10^{0}$ \\
\hline \multicolumn{8}{|c|}{ Microbial Population (CFU/ml) after Day 3 purification using the LEDs } \\
\hline TC & $1.20 \times 10^{3}$ & $2.10 \times 10^{1}$ & NG & NG & NG & NG & NG \\
\hline FC & $1.60 \times 10^{3}$ & $7.60 \times 10^{1}$ & NG & $\mathrm{NG}$ & NG & NG & NG \\
\hline E.coli & $4.90 \times 10^{1}$ & $3.00 \times 10^{0}$ & $\mathrm{NG}$ & $\mathrm{NG}$ & $\mathrm{NG}$ & $\mathrm{NG}$ & $\mathrm{NG}$ \\
\hline THB & $2.70 \times 10^{3}$ & $3.86 \times 10^{2}$ & $2.00 \times 10^{0}$ & $8.00 \times 10^{0}$ & $\mathrm{NG}$ & $\mathrm{NG}$ & $2.00 \times 10^{0}$ \\
\hline
\end{tabular}

NT - Counts before purification, TC - Total Coliform, FC - Fecal Coliform, E.coli -Escherichia coli

THB - Total Heterotrophic Bacteria, NG - No Growth

According to the Canadian Drinking Water Quality Guideline (Facts on Drinking Water, 2016) the maximum acceptable level for fecal coliform, total coliforms and E.coli are 'none detectable per $100 \mathrm{~mL}$ '. This simply means that for every $100 \mathrm{~mL}$ of drinking water tested, no coliforms should be detected. As shown in Table 2, all the light sources registered a reduction to zero ( 0 ) count after Day 1 of purification in all the measured coliform and bacteria studied. Some counts were, however, recorded after Day 2 and 3 of purification for some of the light sources for some of the coliform and bacterial studied. It is known that purification effectiveness is a function of the contact time and an increase in temperature beyond the value appropriate for drinking water influences the rate of purification reactions. 
Temperatures exceeding the required temperature might have led to the formation of bio-films on internal surfaces (Ainsworth 2004). Bio-films are known to contain several living heterotrophic bacteria, fungi, protozoa, nematodes and crustaceans. It can be deduced from the temperature graph in Figure 6 that the temperature within the purification chamber increased after Day 1 and could be the reason for the observed counts thereafter. Also the microbial re-growth observed at the end of Day 2 may be due to the organic matter present in the water samples (as depicted in Figure 8b).

With respect to the control sample it will be observed that although it was kept in a dark environment there was a reduction in all the counts with time after Day 1 . This means that other phenomenon aside photo-degradation might be taking place. According to a study (Tortora, Funke, \& Case, 2010), bacterial populations follow a sequential series of growth phases; the lag, exponential growth, stationary and logarithmic-decline. The observed reduction may be attributed to the stationary and logarithmic-decline phases of their growth curve. At the later stage of the stationary phase, increased cell density often causes an accumulation of organic acids and other toxic bio-chemicals as a result of depletion of nutrients and oxygen. In the logarithmic decline phase, limiting factors intensify and the population shows a decline leading to some cells going into dormancy although they remain viable but do not grow. Some cells enter a starvation mode that helps them resist the lack of nutrients (Talaro \& Chess, 2015).

\section{Conclusion}

In this study, the use of LEDs radiating in the ultra-violet and visible spectral regions for the purification of handdug well-water samples have been demonstrated to have a great potential. The UV LED radiated at $396 \mathrm{~nm}$ while the visible LEDs, blue, green, red and white radiated at peak wavelengths of $447 \mathrm{~nm}, 510 \mathrm{~nm}, 629 \mathrm{~nm}$ and $442 \mathrm{~nm}$ respectively. The white LED also exhibited a broad band ranging from $520 \mathrm{~nm}$ and $626 \mathrm{~nm}$. The purification was carried out for three (3) days in specially constructed chambers, and the efficiency and quality of purification periodically monitored using two techniques: laser-induced fluorescence spectroscopy and bacteria and Total Heterotrophic Bacteria count. The laser-induced fluorescence of the samples was determined for each light source and the peak fluorescence intensities at $526 \mathrm{~nm}$ (Raman water peak) and DOM fluorescence intensity at $550 \mathrm{~nm}$ determined. Using the fluorescence intensity of purified drinking water as reference, the fluorescence intensity ratio was calculated at these two wavelengths after each day of purification and for each light source.

The decrease in the fluorescence intensity ratio with time at the two wavelengths for the various light sources generally indicated the extent of photo-degradation of the water samples, characterized by the slope of the line. The steeper the slope the greater is the rate and extent of photo-degradation. Comparing the values of the slopes at both wavelengths, it was clear that the red and green LEDs proved most efficient in the degradation process, while the UV was the least efficient due to the characteristics of the DOM.

Samples were taken before and after exposure to the LEDs and were analyzed with culture techniques. A reduction in the coliform bacteria and Total Heterotrophic Bacteria counts was observed throughout the study. In particular, counts reduced to zero after the first day of irradiation for all light sources, after which microbial re-growths was observed for some light sources. We posit that this re-growth may be due to the presence of some DOM remaining and subsequent over-heating may have led to the formation of bio-films within the water samples. The sample stored in a dark environment also exhibited a reduction in its fluorescence intensity and coliform bacteria and Total Heterotrophic Bacteria counts with time. The observed reduction may be attributed to the stationary and logarithmic-decline phases of the growth curve of bacterial population where the intensification of limiting factors leads to a population decline.

Light radiation based water purification has a great potential as nothing is added except the energy which does the killing of the bacteria and therefore does not form any purification by-products. This technique is therefore amendable for domestic water purification as it is easy to use, inexpensive and dependable for reducing waterborne pathogens.

\section{References}

Adeboye, M. O. (2014). Disinfection of Escherichia Coli in Water Using Ultraviolet LEDs (Master thesis, University of Eastern Finland, Finland).

Amanidaz, N., Zafarzadeh, A., \& Mahvi, A. H. (2015). The Interaction between heterotrophic bacteria and coliform, fecal coliform, fecal Streptococci bacteria in the water supply networks. Iranian journal of public health, 44(12), 1685-1692.

Barcelona, M. J. (1984). TOC Determinations in Ground Water. Ground Water, 22, 18-24. https://doi.org/10.1111/j.1745-6584.1984.tb01471.x

Bartram, J., Cotruvo, J. A., Exner, M., Fricker, C., \& Glasmacher, A. (Eds.). (2003). Heterotrophic plate counts and drinking-water safety. IWA publishing. 
Bowker C., Sain A., Shatalov M., \& Ducoste J. (2011). Microbial UV fluence-response assessment using a novel UV- LED collimated beam system. Water Research, 45, 2011-2019. https://doi.org/10.1016/j.watres. 2010.12.005

Cape Coast. (2017). In Wikipedia, the free encyclopedia. Retrieved June 6, 2017, from https://en.wikipedia.org/wiki/Cape_Coast

Chin, Y. P., Aiken, G. R., \& O’Loughlin, E. (1994). Molecular weight, polydispersity and spectroscopic properties of aquatic humic substances. Environ. Sci. Technol., 28, 1853-1858. https://doi.org/10.1021/es00060a015

Chiou, C. T., Malcolm, R. L., Brinton, T. I., \& Kile, D. E. (1986). Water solubility enhancement of some organic pollutants and pesticides by dissolved humic and fulvic acids. Environ Sci Technol, 20(5), 502-508. https://doi.org/10.1021/es00147a010

Chomycia, J. C., Hernes, P. J., Harter, T., \& Bergamaschi, B. A. (2008). Land management impacts on dairyderived dissolved organic carbon in ground water. J Environ Qual, 37(2), 333-343. https://doi.org/10. 2134/jeq2007.0183

Chopra, A. K., \& Houston, C. W. (1999). Enterotoxins in Aeromonas-associated gastroenteritis. Microbs Infect., 1(13), 1129-1137. https://doi.org/10.1016/S1286-4579(99)00202-6

Coliform Bacteria, 2016, DOH 331-181 Revised. (2016). Retrieved from http://www.doh.wa.gov/portals/1/ Documents/Pubs/331-181.pdf

Contaminant Candidate List. (2016). Retrieved from https://www.epa.gov/ccl/definition-contaminant

Copa, W. M., \& Gitchel, W. B. (1981). U.S. Patent No. 4,265,747. Washington, DC: U.S. Patent and Trademark Office.

Crawford, M. H., Banas, M. A., Rose, M. P., Ruby, D. S., Nelson, J. S., Boucher, R. \& Allerman A. A. (2005). Final LDRD report: ultraviolet water purification systems for rural environments and mobile applications. Mexico and California: Sandia National Laboratory. SAND2005-7245.

Crook, M. J. (2011). A comparative study into disinfection efficiency of traditional UV and UV-LEDs. Cranfield University.

Facts on Drinking Water. (2016). Retrieved from http://www2.gnb.ca/content/dam/gnb/Departments/hs/pdf/en/HealthyEnvironments/water/Coliforme.pdf

Foulquier, A., Mermillod-Blondin, F., Malard, F. \& Gilbert, J. (2011). Response of sediment biofilm to increased dissolved organic carbon supply in groundwater artificially recharged with stormwater. J. Soils Sediments, 11, 382-393. https://doi.org/10.1007/s11368-010-0323-2.

Geldreich, E. E. (1996). Microbial quality of water supply in distribution systems. Florida: CRC Press, Inc..

Ghana Standards Authority. (2009). Water Quality Specification for Drinking, GS 175-1:2009.

Gondal, M. A., Dastageer, M. A., \& Khalil, A. (2009). Synthesis of nano-WO 3 and its catalytic activity for enhanced antimicrobial process for water purification using laser induced photo-catalysis. Catalysis Communications, 11(3), 214-219. https://doi.org/10.1016/j.catcom.2009.10.011.

Griebler, C., \& Lueders, T. (2009). Microbial biodiversity in groundwater ecosystems. Freshwater Biol., 54, 649677. https://doi.org/10.1111/j.1365-2427.2008.02013.x.

Hamamoto, A., Mori, M., Takahashi, A., Nakano, M., Wakikawa, N., Akutagawa, M., ... \& Kinouchi, Y. (2007). New water disinfection system using UVA light-emitting diodes. Journal of applied microbiology, 103(6), 2291-2298.

Hamamoto, A., Mori, M., Takahashi, A., Nakano, M., Wakikawa, N., Akutagawa, M., ... \& Kinouchi, Y. (2007). New water disinfection system using UVA light-emitting diodes. Journal of applied microbiology, 103(6), 2291-2298. https://doi.org/10.1111/j.1365-2672.2007.03464.x

Helmer, R., Hespanhol, I., Supply, W., Council, S. C., Organization, W. H., \& Press, C. (1997). Water pollution control: a guide to the use of water quality management principles (pp. 400-402). https://doi.org/10.4324/ 9780203477540

Hsu, F-C., Shieh, Y., Van-Duin, J., Beekwilder, M., \& Sobsey, M. D. (1995). Genotyping male-specific RNA coliphages by hybridization with oligonucleotide probes. Appl. Environ Microb, 61, 3960-3966. 
Ibrahim, M. A. S., MacAdam, J., Autin O., \& Jefferson, B. (2014). Evaluating the impact of LED bulb development on the economic viability of ultraviolet technology for disinfection. Environmental Technology for Disinfection, 35(4), 400-406. https://doi.org/10.1080/09593330.2013.829858

Jo, W. K. (2013). Purification of aromatic hydrocarbons via fibrous activated carbon/photocatalytic composite coupled with UV light-emitting diodes. Environmental Technology, 34, 1175-1181. https://doi.org/10.1080/ 09593330.2012.743591. PMid:24191450.

Leenheer, J., Malcolm, R., McKinley, P., \& Eccles, L. (1974). Occurrence of dissolved organic carbon in selected ground-water samples in the United States. J Res US Geol Surv, 2, 361-369.

Ministry of Health (MOH). (1999). Medium term Health Strategy towards Vision 2020. Ministry of Health, Accra, Ghana.

Nelson, K. Y., McMartin, D. W., Yost, C. K., Runtz, K. J., \& Ono, T. (2013). Point-of-use water disinfection using UV light-emitting diodes to reduce bacterial contamination. Environmental Science and Pollution Research, 20(8), 5441-5448. https://doi.org/10.1007/s11356-013-1564-6

Oppenheimer, J. A., Jacangelo, J. G., Laine, J-M., \& Hoagland, J. E. (1997). Testing the equivalency of ultraviolet light and chlorine for disinfection of wastewater to reclamation standards. Water Environ. Res., 69, 14-24. https://doi.org/10.2175/106143097X125137

Payment, P. (1999). Heterotrophic bacteria. In AWWA manual of water supply practices (pp. 83-87). AWWA M48. Waterborne pathogens. American Water Works Association, Denver, Colorado.

Pepper, I. L., Rusin, P., Quintanar, D. R., Haney, C., Josephson, K. L., \& Gerba, C. P. (2004). Tracking the concentration of heterotrophic plate count bacteria from the source to the consumer tap. Int. J. Food Microbiol., 92, 289-295. https://doi.org/10.1016/j.ijfoodmicro.2003.08.021

Piper, A. M. (1994). A graphic procedure in the Geochemical interpretation of water analyses. Am. Geophys. Un. Trans., 25, 914-923.

Richard, A. (2004). Safe piped water: Managing microbial water quality in piped distribution systems (pp. 25130). World Health Organization (WHO).

Sackey, S. S., Vowotor, M. K., Owusu, A., Mensah-Amoah, P., Tatchie, E. T., Sefa-Ntiri, B., Hood, C. O., Atiemo, S. M. (2015). Spectroscopic Study of UV Transparency of Some Materials. Environment and pollution, 4(4). https://doi.org/10.5539/ep.v4n4p1

Sharikova, A. V. (2009). UV laser and LED induced fluorescence spectroscopy for detection of trace amounts of organics in drinking water and water sources. Graduate Theses and Dissertations. Retrieved from http://scholarcommons.usf.edu/etd/15

Singer, P. C. (1994). Control of disinfection by-products in drinking water. J Environ Eng, 120(4), 727-744. https://doi.org/10.1061/(ASCE)0733-9372(1994)120:4(727)

Stine, S. W., Pepper, I. L., \& Gerba, C. P. (2005). Contribution of drinking water to the weekly intake of heterotrophic bacteria from diet in the United States. Water Res., 39, 257-263. https://doi.org/10.1016/j. watres.2004.09.010

Tebbute, T. (1992). Sustainable Water Development: Opportunities and Constraints Water Int., 13, 189.

Vilhunen S., Särkkä H., \& Sillanpää, M. (2009). Ultraviolet light-emitting diodes in water disinfection. Environmental Science and Pollution Research, 16, 439-442. https://doi.org/10.1007/s11356-009-0103-y

Villanueva, C. M., Cantor, K. P., Grimalt, J. O., Malats, N., Silverman, D., Tardon, A., ... \& Marcos, R. (2006). Bladder cancer and exposure to water disinfection by-products through ingestion, bathing, showering, and swimming in pools. American journal of epidemiology, 165(2), 148-156. https://doi.org/10.1093/aje/kwj364

WHO/UNICEF. (2015). WHO/UNICEF Joint Monitoring Programme (JMP) Report 2015.

\section{Copyrights}

Copyright for this article is retained by the author(s), with first publication rights granted to the journal.

This is an open-access article distributed under the terms and conditions of the Creative Commons Attribution license (http://creativecommons.org/licenses/by/4.0/). 